\title{
Twin-twin transfusion syndrome: revisited
}

\section{Rinki Tiwari*, Shikha Yadav, Ratna Thakur}

\begin{abstract}
Department of Obstetrics and Gynaecology, Sri Aurobindo Medical College and PG Institute, Indore, Madhya
\end{abstract} Pradesh, India

Received: 22 April 2014

Accepted: 4 May 2014

\section{*Correspondence:}

Dr. Rinki Tiwari,

E-mail: drrinkitiwari2012@gmail.com

(C) 2014 Tiwari R et al. This is an open-access article distributed under the terms of the Creative Commons Attribution Non-Commercial License, which permits unrestricted non-commercial use, distribution, and reproduction in any medium, provided the original work is properly cited.

\section{ABSTRACT}

Twin to twin transfusion syndrome is a very rare disorder complicating monozygotic monochorionic pregnancy. Here we are reporting a case of Twin to twin transfusion syndrome in 20 year old primigravida woman. Amnioreduction was planned as a treatment option. However patient underwent premature labor and deliver male twins both of which died later on.

Keywords: Twin to twin transfusion syndrome, Amnioreduction

\section{INTRODUCTION}

Twin to Twin Transfusion Syndrome (TTTS) results from an imbalance of blood flow through arteriovenous placental anastomoses between the two fetuses. ${ }^{1,2}$ It complicates $10-20 \%$ of monozygous twin gestations, with an incidence of $4-35 \%$ in the USA. ${ }^{3,4}$ Severe TTTS is reported to occur in $5.5-17.5 \%$ of cases. ${ }^{5}$ Literature is available regarding TTTS from developed countries but there is scarcity in data from India. Here we are describing a case of TTTS with no other complication.

\section{CASE REPORT}

A 20 year old primigravida woman visited to department of obstetrics and gynaecology, Sri Aurobindo medical college and PG institute; with a complaint of lower abdominal pain since last 2 days. She had history amenorrhea since six and half months. General and systemic examination was normal. On obstetric examination uterus was 36 weeks size, fetal parts \& fetal heart sound could not be localised. Per speculum and vaginal examination was normal.

Routine investigations were normal. Ultrasonography revealed live twin gestation of 26 weeks with single placenta, polyhydramnios [Amniotic Fluid Index (AFI) was $45 \mathrm{~cm}$ ] in one sac \& oligohydramnios (AFI was 1 $\mathrm{cm}$ ) in other with non-visualization of fetal bladder. Color Doppler was normal. Patient was planned for amnioreduction but went into premature labor \& delivered male twins weighing 565 grams (plethoric) \& 440 grams (pale \& hypovolemic) which died later (Figure 1). Puerperium was uneventful.

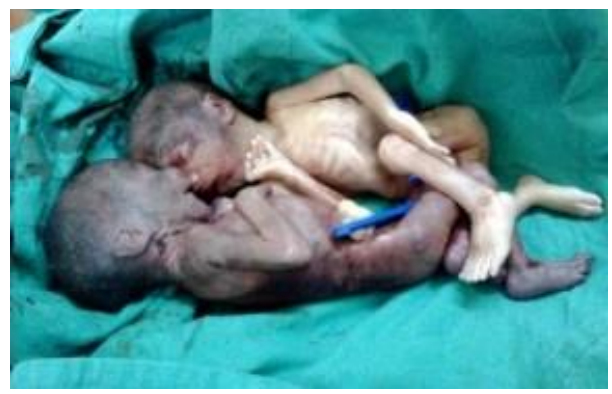

Figure 1: Male twins with weights of 565 grams (plethoric) and 440 grams (pale \& hypovolemic).

\section{DISCUSSION}

Twin to Twin Transfusion Syndrome (TTTS) is a specific complication of monozygotic monochorionic twins resulting from transfusion of blood from one twin to the other through a deep, artery to vein placental vascular 
anastomosis. Subsequently, the donor twin becomes anemic, hypovolemic, hypotensive, and hypoproteinemic. Donor twin undergoes intrauterine growth retardation, and occasionally develops oligohydramnios. In contrast, the recipient twin is heavier, polycythemic, hypervolemic, and faces complications of hyperviscosity of the blood such as hyperbilirubinemia, intravascular thrombosis and cardiac failure.

The degree of severity of the twin transfusion depends on the duration of pregnancy, structural alterations of the vasculature such as vessel caliber, quality of the anastomoses, and the presence/absence of vascular communication in the opposite direction to compensate for the haemodynamic imbalance, and chronicity of transfusion. Severe oligohydramnios can result in the stuck twin phenomenon in which the twin appears in a fixed position against the uterine wall. ${ }^{6-8}$

TTTS is associated with the death of one or both fetuses in more than $70-80 \%$ of untreated pregnancies, particularly if problems developed before 28 weeks' gestation. ${ }^{9}$ The main treatment options in chronic TTTS are serial amnioreduction and Fetoscopic Laser Coagulation of Communicating vessels (FLOC). Data from studies suggested survival rates following serial amnioreduction of $37-60 \%,{ }^{9-12}$ and treatment by laser photocoagulation increases the survival rate upto 55$73 \% .^{13,14}$

Therefore endoscopic laser coagulation of anastomotic vessels should be considered in the treatment of all stages of TTTS to improve perinatal and neonatal outcome. Amnioreduction can be retained as a treatment option for those situations in which the expertise for laser coagulation is not available.

Funding: No funding sources

Conflict of interest: None declared

Ethical approval: Not required

\section{REFERENCES}

1. Huber A, Hecher K. How can we diagnose and manage twin-twin transfusion syndrome? Best Pract Res Clin Obstet Gynaecol. 2004;18:543-56.
2. Lewi L, Van Schoubroeck D, Gratacos E, Witters I, Timmerman D, Deprest J. Monochorionic diamniotic twins: complications and management options. Curr Opin Obstet Gynaecol. 2003;15:177-94.

3. Harkness UF, Crombleholme TM. Twin-twin transfusion syndrome: where do we go from here? Semin Perinatol. 2005;29:296-304.

4. Crombleholme TM. The treatment of twin-twin transfusion syndrome. Semin Pediatr Surg. 2003; 12:175-81.

5. Quintero RA. Twin-twin transfusion syndrome. Clin Perinatol. 2003;30:591-600.

6. Cincotta RB, Fisk NM. Current thoughts on twintwin transfusion syndrome. Clin Obstet Gynaecol. 1997;40:290-302.

7. Berghella V, Kaufmann M. Natural history of twintwin transfusion syndrome. J Reprod Med. 2001;46:480-4.

8. Fox C, Kilby MD, Khan KS. Contemporary treatments for twin-twin transfusion syndrome. Obstet Gynaecol. 2005;105:1469-77.

9. Gonsoulin W, Moise KJ Jr, Kirshon B, Cotton DB, Wheeler JM, Carpenter RJ Jr. Outcome of twin-twin transfusion diagnosed before 28 weeks of gestation. Obstet Gynaecol 1990;75:214-6.

10. Urig MA, Clewell WH, Elliot JP. Twin-twin transfusion syndrome. Am J Obstet Gynaecol. 1990;163:1522-6.

11. Saunders NJ, Snijders RJM, Nicolaides KH. Therapeutic amniocentesis in twin-twin transfusion syndrome appearing in the second trimester of pregnancy. Am J Obstet Gynaecol. 1991;166:820-4.

12. Trespidi L, Boschetto C, Caravelli E, Villa L, Kusterman A, Nicolini U. Serial amniocenteses in the management of twin-twin transfusion syndrome: when is it valuable? Fetal Diag Ther. 1997;12:15-20.

13. De Lia JE, Kuhlmann RS, Harstad TW, Cruikshank DP. Fetoscopic laser ablation of placental vessels in severe previable twin-twin transfusion syndrome. Am J Obstet Gynaecol. 1995;172:1202-8.

14. Ville Y, Hecher K, Gagnon A, Sebire N, Hyett J, Nicolaides KH. Endoscopic laser coagulation in the management of severe twin-twin transfusion syndrome. Br J Obstet Gynaecol 1998;105:446-53.

DOI: $10.5455 / 2320-1770 . i j r \operatorname{cog} 20140648$

Cite this article as: Tiwari R, Yadav S, Thakur R.

Twin-twin transfusion syndrome: revisited. Int J

Reprod Contracept Obstet Gynecol 2014;3:491-2. 